\title{
Capital Budgeting Applied to Serbian Poplar Plantations
}

\author{
Ljiljana Keča ${ }^{1 *}$
}

(1) University of Belgrade, Faculty of Forestry, Kneza Viseslava 1, RS-11030 Belgrade, Serbia

Citation: KEČA LJ 2018 Capital Budgeting Applied to Serbian Poplar Plantations.

* Correspondence: e-mail: liiljana.keca@sfb.bg.ac.rs South-east Eur for 9 (2): 123-130. DOI: https://doi.org/10.15177/seefor.18-12

Received: 14 Jul 2018; Revised: 26 Sep 2018; Accepted: 4 Oct 2018; Published online: 15 Oct 2018

\begin{abstract}
Background and Purpose: Capital budgeting is the process in which a business determines and evaluates potential large expenses or investments. These expenditures and investments include projects such as building a new plant or investing in a long-term venture. In the case of poplar plantations in Serbia, a prospective project's lifetime cash inflows and outflows can be assessed in order to determine whether generated potential returns meet a sufficient target benchmark, also known as "investment appraisal". The purpose of this study is to show relative profitability of alternative courses of action in poplar plantations.

Material and Methods: The investigated plantations were established from Populus x euramericana cl. I-214 on different soil types, situated in north-western part of Serbia, with planting spacing $6 \times 3 \mathrm{~m}$, differently aged, mainly for technical wood production. The data used in this study were collected from the management and materials books of the "Vojvodinašume" Public Forest Enterprise, which is the official owner of these stands. All of the plantations are state-owned. At the end the supply chain of poplar wood production is presented. Different capital budgeting techniques and different discount rates are employed to determine which types of poplar plantations, treated as separate projects, will or not will yield the most return over an applicable period of time.

Results and Conclusions: The financial effects for sample plot plantations were first evaluated with an external funder prerequisite of $12 \%$ discount rate, and continued with different investment appraisal discount rates. For the discount rate $r=12 \%$, all tested areas had a negative net present value (NPV). Average internal rate of return (IRR) is $5.63 \%$ and payback period is acceptable for the investor at $6 \%$ and less. The average benefit-cost analysis amount is 0.36 for all stands with a discount rate of $r=12 \%$.
\end{abstract}

Keywords: capital budgeting, strategy, discount rate, poplar, costs, revenues

\section{INTRODUCTION}

Financial appraisals in forestry are based on standard investment appraisal techniques. In such analysis we take into account the frequently long time period lapsing between initiating forest activities and obtaining returns from trees [1]. Forestry schemes are generally characterized by heavy initial costs, low recurrent costs (an advantage which will tend to be discounted relative to initial costs) and delayed benefits [2]. Poplar rotation is one of the shortest in European forestry, and production of poplar wood requires rational and well-planned management [3].

Capital budgeting is used to show the relative profitability of alternative courses of action [4]. The poplar plantations have been chosen because of the relatively short rotation period compared to other tree species $[3,5]$.
Yield classes in hybrid poplar plantations (P. xeuramericana cl. 1-214) are high in Serbia [6]. Preparation of the ground and soil for afforestation is the most expensive operation in the production cycle [7]. High costs are encountered at the stage of plantation establishment (chipping of tree stumps, ploughing, planting, protection, etc.) [3]. Major cuts in plantations of clone poplars belong to the group of clear felling [8]. "Marking of trees for cutting in restoration is carried out along the border line that is included in the area of clear cut. Harvesting is realized at a time when there is no risk of sudden arrival of high water, to effectively protect produced assortments during floods. When performing cuts there must be taken into account that felled trees do not intersect and the stump height does not exceed $1 / 4$ of diameter. Cutting of felled timber is adapted to market conditions, to achieve maximum financial effects (greater participation of technical wood in 
relation to the physical, waste is minimized) and performed by a qualified stuff" [9].

Costs are a very important element of an investment. When there is a significant lapse of time between the start of costs being incurred and the end of the period, such as in poplar plantations, in which all costs and benefits arise from the original expenditure, this is considered to be an investment [10]. "Structure of costs of major felling in cultures of clone poplars in Ravni Srem is composed of two segments of direct costs: costs of felling and work up and costs of extracted assortments. The costs of felling and work up are related to chainsaw and labor force. The second segment consists of the costs of extraction of produced assortments" [7].

The goals of the work reported in this paper were: (i) to apply capital budgeting to poplar plantations, based on the analysis of the present value of costs and revenues over a different time period, and (ii) to present the supply chain of poplar wood production and test the sensitivity of these values to possible changes in the levels of costs and revenues.

\section{MATERIAL AND METHODS}

There are four main groups of values identified in forestry: forestry values which derive from forest-related activities by forest managers and the upstream and downstream connections with other parts of the economy arising from such forestry activities; 'shadow' values arise as a result of other economic activities benefiting or experiencing loss as a result of forestry; non-market values are the external effects associated with forests and woodland; and social values $[1,11]$. Critics of standard investment criteria based on discounting have argued that these introduce a bias in favor of investment projects which impose high private or social costs in the future, or after a long delay, but have lower capital costs at the present time or in the near future [2]. Forestry projects of all kinds will be disfavored relative to other types of projects of shorter term because of the inherently long gestation period involved in tree growth [13]. Generally, final goal of investment process is to maximize stakeholder wealth or value of the firm, making capital budgeting part of long term investment appraisals [14].

This paper identifies a number of different kinds of investment decisions in which a long-time horizon is involved and for which the application of the conventional, relatively high discount rates used in less developed countries creates problems.

The aim of the study was to conduct an analysis of costs and receipts of artificial poplar plantations on different fluvisols considering a span of rotation between 25 and 42 years, as well as in different discount rates (4-12\%) [3]. The primary methods used are dynamic methods of investment calculation $[15,16]$. These methods include net present value (NPV), internal rate of return (IRR), payback period (PBP), and cost-benefit analysis (R) $[14,17,18]$.

The data used in this study were collected regarding costs during years $0-5$ (soil preparation, planting, care and protection, etc.) obtained from the archives of "Vojvodinašume" Public Forest Enterprise, the forest enterprise which managed the studied plantations, according to the age established at the plantation $[3,5,6]$ and expressed per unit area of 1 ha at the prices in force in January 2016. Land value was not taken into account since the objective of the study was not to determine optimal treatments and rotations for poplar [8, 19].

The investigated plantations were established from Populus x euramericana $\mathrm{cl}$. I-214 in the north-western part of Serbia, with planting spacing of $6 \times 3 \mathrm{~m}$ ( 555 trees per ha), used for technical wood production. Thirteen study plots, i.e. 55 stands, aged 24-42 years, with a total area of 331.05 ha were assessed. The data collected are linked to different types of soil belonging to site classes I-V $[3,5,6]$.

The level of the discount rate is of paramount importance in forestry owing to the large effects of a small change in rate when used to discount values over long periods of time [4]. The discount rate used in the public sector generally is related to the rate of return on capital in the private sector of the industry and commerce [20]. Discount rates of 3, 5 and $7 \%$ have been employed in an attempt to cover the range of real rates of return likely to be available from alternative investments open to private investors in forestry [10, 21, 22]. First in this research the discount rate of $12 \%$ was chosen, a traditional common choice for developing countries according to Gittinger [23]. Poplar plantations are not profitable at discount rates in the range of $10-15 \%$, as it was still used some time ago in assessing funding opportunities in the economies of developing and transition countries [24]. The National Bank of Serbia discount rate was in 2005 at $8.8 \%$, while today it is at $3.0 \%$. Dinar loans for long-term lending of non-financial corporations nowadays are around 6\%. Since the interest rates have decreased considerably since the financial crisis, in forestry it is most convenient to account for investment risk by adding a risk premium to the risk-free discount rate when computing present values of expected revenues which are uncertain [25]. After a review of the literature on the discount rate in economics and forestry, it is most useful to use IRR, while the opportunity cost of capital is considered in the establishment of a shadow price of investment [26].

Sensitivity Analysis is the calculating procedure used for prediction of the effect of changes of input data on output results of one model [27]. This procedure is often used in investment decision making, in the example of poplar plantations in this case, related to the investment project evaluation under conditions of uncertainty [28]. In this case sensitivity analysis [29] is a common way to consider uncertainty (by changing input variables and evaluating the effects on target variables) in poplar plantation studies.

\section{RESULTS AND DISCUSSION}

The financial effects for sample plot plantations were estimated using different discount rates (Table 1). For a discount rate $r=12 \%$, all tested areas had a negative NPV from -1585.84 to $-2134.80 € \cdot h^{-1}$, regardless of age and site quality. The discount rate of $6 \%$ can be accepted by shorter production cycles in younger stands (to the age of 28 years) on better sites (alluvial semigley) [3, 5]. The value of assortments by the price list of "Vojvodinašume" Public Forest Enterprise, which manages these forests, ranges from 11.088 to 23.676 $€ \cdot h^{-1}[9]$. Cost, revenue and profit are three most important factors in determining the success of management in poplar plantations [30]. 


\begin{tabular}{|c|c|c|c|}
\hline $\begin{array}{l}\text { Input values: } \\
\text { Costs } \\
\text { Revenues } \\
\text { Ages } \\
\text { Discount rates } \\
\text { Area } \\
\text { Plant denisty } \\
\text { Soil type }\end{array}$ & & $\begin{array}{l}\text { Output values of criteria: } \\
\mathrm{NPV}_{(\mathrm{r}=12 \%)}=-1585.84 \text { to }-2161.99 € \cdot \mathrm{ha}^{-1} \\
\mathrm{IRR}=5.63 \\
\mathrm{PBP}_{(\mathrm{r}=4 \%)}=19 \text { years } \\
\mathrm{R}=0.36\end{array}$ & \\
\hline & $\begin{array}{l}\text { Calculating values: } \\
\text { NPV, IRR, PBP, R }\end{array}$ & & $\begin{array}{l}\text { Sensitivity } \\
\text { analysis }\end{array}$ \\
\hline
\end{tabular}

FIGURE 1. Calculation of individual criteria using input and output values.

TABLE 1. Capital budgeting on poplar plantation on sample plots in Serbia

\begin{tabular}{|c|c|c|c|c|c|c|c|c|}
\hline $\begin{array}{c}\text { Study } \\
\text { plot no. }\end{array}$ & $\begin{array}{l}\text { Soil } \\
\text { Type }\end{array}$ & $\begin{array}{l}\text { Site } \\
\text { Class }\end{array}$ & $\begin{array}{l}\text { Age } \\
\text { (years) }\end{array}$ & Area (ha) & $\begin{array}{c}\text { NPV } \\
p=12 \%\left(€ \cdot h a^{-1}\right)\end{array}$ & IRR (\%) & $\begin{array}{c}\text { PBP } \\
\text { for } p=4 \% \text { (years) }\end{array}$ & $\mathbf{R}$ \\
\hline 1. & $\mathrm{RC} / \mathrm{HGL}$ & IV & 24 & 25.00 & -1743.02 & 5.20 & 19 & 0.421 \\
\hline 2. & AS/ASG & 1 & 26 & 36.75 & -1838.60 & 6.94 & 19 & 0.349 \\
\hline 3. & AS/ASG & 1 & 26 & 2.33 & -1700.41 & 5.83 & 19 & 0.467 \\
\hline 4. & AS/ASG & 1 & 26 & 9.87 & -1585.84 & 6.18 & 19 & 0.407 \\
\hline 5. & AS/ASG & I & 26 & 1.32 & -1746.22 & 6.12 & 19 & 0.430 \\
\hline 6. & AS/ASG & 1 & 28 & 32.57 & -1813.10 & 5.41 & 19 & 0.373 \\
\hline 7. & AS/ASG & 1 & 29 & 28.82 & -1872.78 & 5.84 & 19 & 0.351 \\
\hline 8. & $\mathrm{LC} / \mathrm{HFL}$ & III & 29 & 33.81 & -1877.35 & 4.32 & 19 & 0.388 \\
\hline 9. & $\mathrm{LC} / \mathrm{HFL}$ & III & 29 & 51.49 & -1791.41 & 5.36 & 19 & 0.390 \\
\hline 10. & $\mathrm{LC} / \mathrm{HFL}$ & III & 31 & 58.15 & -1940.66 & 5.35 & 19 & 0.323 \\
\hline 11. & ASG & I & 37 & 5.80 & -1999.57 & 6.10 & 19 & 0.310 \\
\hline 12. & ASG & I & 42 & 6.62 & -2161.99 & 5.51 & 19 & 0.240 \\
\hline 13. & $\alpha / \beta-\beta$ gley & V & 42 & 38.52 & -2134.80 & 4.43 & 19 & 0.242 \\
\hline $\begin{array}{c}\text { Total/ } \\
\text { Average }\end{array}$ & & & & 331.05 & & & & 0.36 \\
\hline
\end{tabular}

RC - fossil hydromorphic black soil (humosemigley) on loess-alluvium; HGL - humogley; ASG - alluvial semigleyfossil hydromorphic black soil on loess-alluvium; HFL - humofluvisoil; $\alpha$ / B-B glev; $p$ - discount rate; NPV - net present value; IRR - internal rate of return; PBP - pavback period; R - benefit- cost analvsis.

TABLE 2. Sensitivity analysis of NPV in relation to relative changes of $T_{p}$ - costs and $P_{p}$ - revenues $(p=4$ and 6\%)

\begin{tabular}{|c|c|c|c|c|c|}
\hline \multirow{2}{*}{$\begin{array}{l}\text { Study } \\
\text { plot } \\
\text { number }\end{array}$} & \multicolumn{2}{|c|}{$r=6 \%$} & \multicolumn{2}{|c|}{$r=4 \%$} & \multirow{2}{*}{$\begin{array}{c}\text { Acceptable or not } \\
\text { for investment } \\
\text { in } r=6 \text { and } 4 \%\end{array}$} \\
\hline & $T_{p}$ & $\boldsymbol{P}_{\mathrm{p}}$ & $T_{p}$ & $P_{p}$ & \\
\hline 1. & -0.24 & -0.24 & 0.94 & 0.94 & $+/-$ \\
\hline 2. & -0.41 & -0.41 & 0.78 & 0.78 & $+/-$ \\
\hline 3. & 0.58 & 0.58 & 2.39 & 2.39 & + \\
\hline 4. & -0.09 & -0.09 & 1.29 & 1.29 & $+/-$ \\
\hline 5. & 0.10 & 0.10 & 1.60 & 1.60 & + \\
\hline 6. & 0.08 & 0.08 & 1.86 & 1.86 & + \\
\hline 7. & -0.34 & -0.34 & 1.06 & 1.06 & $+/-$ \\
\hline 8. & -0.36 & -0.36 & 1.02 & 1.02 & $+/-$ \\
\hline 9. & 0.06 & 0.06 & 1.76 & 1.76 & + \\
\hline 10. & -0.40 & -0.40 & 1.14 & 1.14 & +1 \\
\hline 11. & -0.12 & -0.12 & 2.05 & 2.05 & +1 \\
\hline 12. & -1.10 & -1.10 & 0.31 & 0.31 & +1 \\
\hline 13. & -1.03 & -1.03 & 0.42 & 0.42 & +1 \\
\hline
\end{tabular}


By applying sensitivity analysis (Table 2) it can be concluded that "investment under calculation discount rate of $4 \%$ was financially justified in all study cases. The discount rate of $6 \%$ can be accepted by shorter production cycles in younger stands (up to the age of 26-29 years) on better sites (alluvial semigley)" [31]. That is directly connected to IRRs values. The results clearly show an inverse relationship between the IRR and plantation age, and also a direct proportion with the soil type, i.e. IRR are higher for plantations grown (Table 2 ) on stands suitable for poplar production (alluvial semigley) and for shorter rotations and vice versa [5].

IRRs varied in the range of $4.32-6.94 \%$ (average $5.63 \%)$. Internal rates were higher for plantations on good quality soil types and for shorter rotations, and vice versa. "The results clearly show the inverse proportion between discount rate and the age of the plantation, and also direct proportion with soil type, i.e. that discount rates are higher for plantations which are grown on stands suitable for poplar production (alluvial semigley) and for shorter rotations, and vice versa. Stands with higher IRR have priority in investment, and this research includes younger plantations, which refer the investors in poplar production to invest in stands with shorter rotations." [5, 32].

Based on the application of sensitivity analysis of IRR it was concluded that the most unfavourable situation is found in sample plots which are over-matured stands on unfavorable soil type for poplar production. On the other hand, the most favourable situation is found in the stands where the amounts of IRR are not considered to be higher than $12 \%$ in the observed changes of costs and receipts, and they are realized on the level below $70 \%$ of costs or above $130 \%$ of realized receipts [32]. There are commercial banks in Serbia, where one can get a loan with an interest rate of $5 \%$. Private owners can be advised to invest in such a production of poplar wood. On the other hand, the state has interest regarding poplar plantations. Plantations are very efficient in $\mathrm{CO}_{2}$ consuming, as shelterbelts, for flood control, etc. Therefore, the state can stimulate forest owners to invest in poplar production in river banks in the future. Plantations grown on more quality soil types such as alluvial semigley are more profitable [3, 5, 6, 32].

The analysis showed that PBP is practically unacceptable for the investor under the discount rate of $6 \%$. The most favourable situation is with a discount rate of $2 \%$ in younger plantations. The conditions for having rotations up to over-aged stands are utterly unfavorable regarding the payback period, so the credit cannot be repaid under any conditions. This fact supports the conclusion that the production cycle period in poplar plantations should be shortened. In younger stands, the situation is fairly more favorable, so under special conditions the credit should be repaid [33]. Based on the sensitivity analysis for the method of payback period, it can be concluded that the change in receipts and costs in 5\% steps can be represented by an exponential function and that PBP is between 1.3 and 4.6 years. For $p=2 \%$ this ratio is the most favorable both in the case of the changes in receipts and the changes in costs $[5,6,33]$.
Applying the method of cost-benefit it can be concluded that the average amount of $R$ was 0.36 for all studied plots at $12 \%$ discount rate (Table 1$)[5,6,34]$. This means that the costs at a discount rate of $12 \%$ are about 2.8 times higher than the receipts. Based on the sensitivity analysis of the cost-benefit method, it can be concluded that cost benefit ratio for $p=8-12 \%$ is below 1 within the study range of changes in costs and receipts, while for $p=4-6 \%$ there are cases when this ratio is above 1 , at certain degrees of decrease in costs, i.e. the increase in receipts [5, 34]. Nowadays, with the higher awareness of human impact on the environment, benefit/cost analysis is increasingly applied in the evaluation of forest social functions, wildlife conservation, impact on water resources (water supply, acidification and erosion control), landscape management, and greenhouse effect reduction. Forestry is often unable to valorize all of its products on the market, and therefore the social community should support forestry in a way, especially in the realization of the projects dealing with plantation forestry. One of the forms of support could be to enable the use of beneficial interest rates on the means invested in the establishment of new plantations, which are considerably lower than those in other production fields [34].

Based on the results presented above, it is clear that, in practice, it is necessary to improve the position of producers in getting the deficient financial means for investment in poplar cultivation, so as to stimulate the establishment of artificial poplar plantations, especially in the private sector (on private lands, which are unattractive for agricultural production). The investments can be directed to more efficient soil preparation (stump chipping, deep ploughing, etc.), the improvement of interrow tilling, better plant protection against insect pests and phyto-pathogenic fungi (Figure 2) [31, 32].

Forest Management Plans prescribe the rotation period in poplar plantations on 25 years and thus also a certain time of the major harvest, the main income in the cultures of clone poplars. Major cuts in plantations of clone poplars belong to the group of clean felling, i.e. removing all trees from the selected area. The marking of trees for cutting in restoration is carried out along the border line that is included in the area of clean cut. Harvesting is realized at a time when there is no risk of sudden arrival of high water to effectively protect the produced assortments during floods. When performing cuts it must be taken into account that felled trees do not intersect and that stump height does not exceed $1 / 4$ of its diameter. Cutting of felled timber is adapted to market conditions to achieve maximum financial effects (greater participation of technical wood in relation to the physical, while waste is minimized) and performed by qualified staff. The assortments are brought out via forest roads, in the shortest possible time, to the forest stock where wood material is stored in an accessible place and is kept safe from flooding. Technical wood is exported to the forest road by machines (expenses of machine forwarder), while the cellulose wood carries the costs of loading, unloading and stacking (machine expenses - tractors and manpower - loader) [8]. 


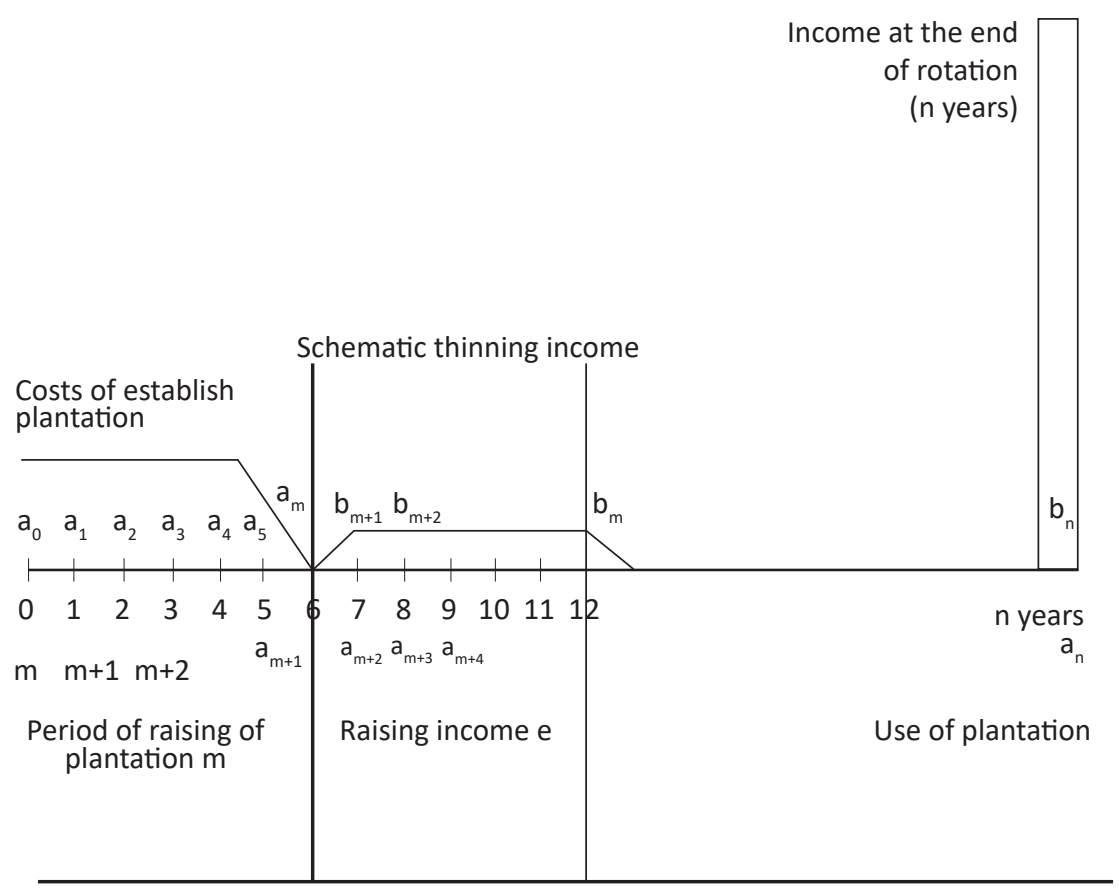

FIGURE 2. Developed model of investment in the establishment of multiannual plantations (Source: [34]).

One of the most significant changes in the paradigm of modern business management is that individual companies no longer compete as solely autonomous entities but rather as supply chains [35]. In Figure 3 the supply network structure, the supply chain business process, and the management process for poplar wood in Serbia are presented. In the Serbian market there is a strong need for F-class assortment of poplar and RII-class, which can lead to the conclusion that wood processing is oriented towards the production of various products of poplar wood, so the range of products from poplar wood expands, as directed for export and for domestic purposes [36]. All wood processing companies are privately owned in the sector of poplar production. All capacities on average amount to about $17,300 \mathrm{~m}^{3} \cdot \mathrm{yr}^{-1}\left(3,000-100,000 \mathrm{~m}^{3} \cdot \mathrm{yr}^{-1}\right)$, and the utilization of the installed capacities is approximately $66 \%(30-90 \%)$ [36]. Wood processing companies are oriented towards the production of multiple products at the same time, such as: timber, boards, lumber, crates and veneer, fiberboard and particleboard [37], and produce approximately $350,000 \mathrm{~m}^{3}$ of poplar wood per year [6]. Figure 3 shows the supply chain of the analyzed companies in poplar wood processing, from the purchase of raw materials, through the processing and sale of the final product.

In the future wood-processing organizations should be directed to better adapt to their operational and development plans of production in accordance with the planned cuttings in forestry and widening capacities. Plantations should be established to meet the demands of the market of poplar wood, especially in Serbia, and the markets in the region. For a long time there has been a great demand on the market for a veneer logs and saw logs, since the producers as a goal have the provision of these assortments [37].

\section{CONCLUSIONS}

Based on the analysis it is clear that it is necessary to improve the position of poplar production in Serbia in the soil types and age which are suitable for such a production, with appropriate site and climate conditions. It is both important for the public and private sector. Also in the future it would be useful to influence investments in cost reduction in poplar production on the one hand, and small and medium enterprises in the sector of wood production to intensify production of final products of poplar wood on the other hand. This is in line with the Common Agricultural Policy of the European Union and the endeavours of the Government of the Republic of Serbia to develop the bioenergy sector [36]. Market analyses are very important, particularly in the field of market supply. In that way they should direct influence production of wood in poplar plantations and shorten the rotation period. The obtained results are not very optimistic when a discount rate of $12 \%$ is applied, but by applying sensitivity analysis the circumstances in which such a production is profitable are emphasized. During the past decade, the interest rates have decreased considerably since the Financial Crisis of 2007-2008, also affecting Serbia. On the other hand, poplar plantations are very efficient in flood control and shelterbelt and in that way have not just an economic, but also an ecological function. 


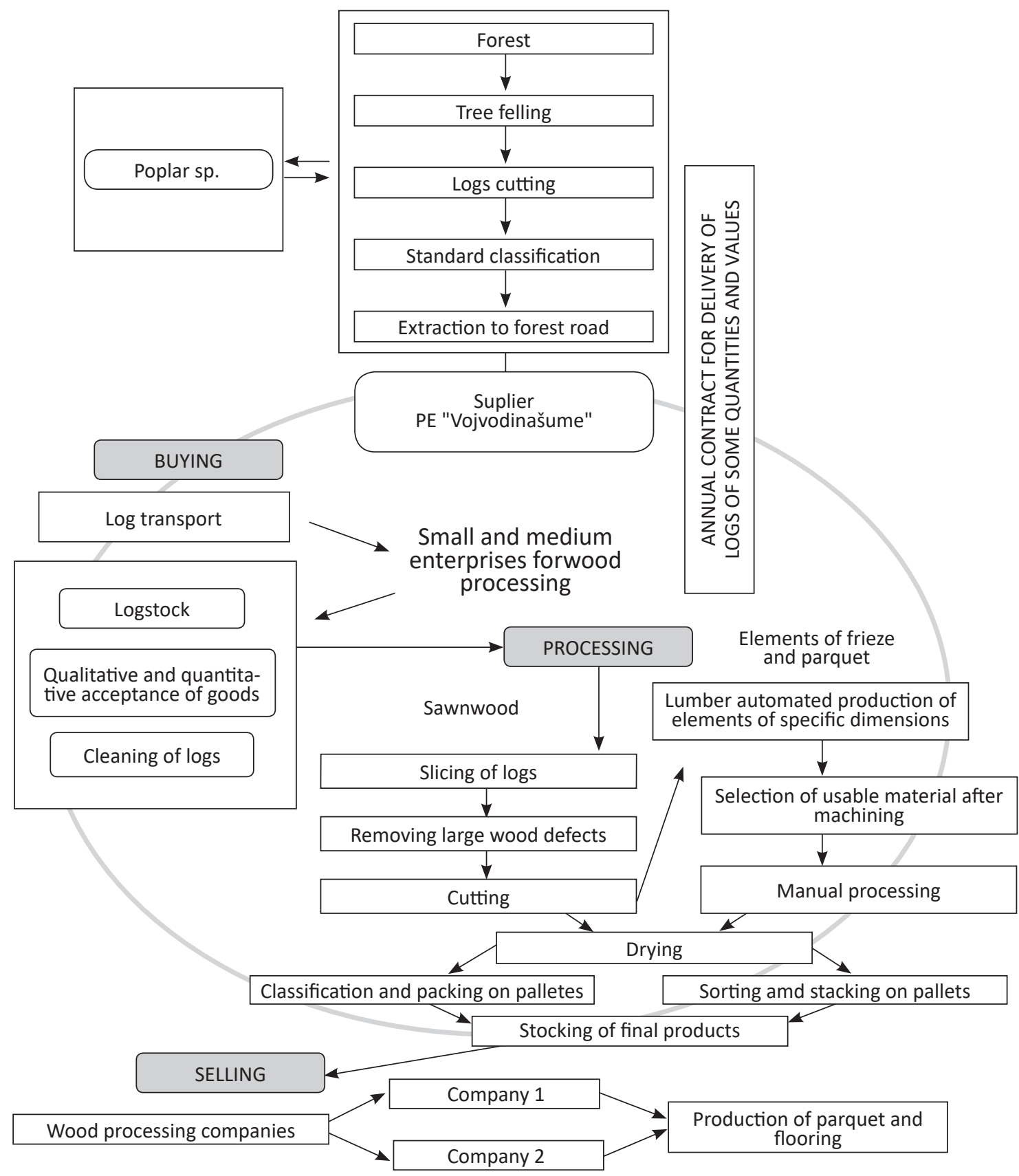

FIGURE 3. Supply chain in poplar wood production (Source: Marčeta M. (unpublished), adapted by Keča Lj.). 


\section{Acknowledgment}

This research was presented on the International Conference SUSTAINABLE FOREST MANAGEMENT FOR THE FUTURE - the role of managerial economics and accounting, IUFRO Unit 4.05.00 - Managerial economics and accounting in Zagreb (10-12 May 2018). The research was supported by a grant from the Ministry of Education and Science of the Republic of Serbia, projects: "Sustainable management of total forest potential in the Republic of Serbia" (TR 37008) and "Forest plantations as the indicator of increasing afforestated areas of Serbia" (TR 31041). The author would also like to thank CA COST ACTION CA 15206 - Payments for ecosystem services - PESFOR-W, COST TN 1401 - CAPABAL and COST ACTION FP 1403 - NNEXT.

\section{REFERENCES}

1. SLEE B, ROBERTS D, EVANS R 2004 Forestry in the rural economy: a new approach to assessing the impact of forestry on rural development. Forestry 77 (5): 441-453. DOI: https://doi.org/10.1093/forestry/77.5.441

2. LIVINGSTONE I, TRIBE M 1995 Projects with long time horizons: their economic appraisal and the discount rate. Project Appraisal 10 (2): 66-76. DOI: https://doi.org/10.108 0/02688867.1995.9726978

3. KEČA LJ, KEČA N, PAJIĆ S 2011 Investment Appraisal of Poplar Plantations in Serbia. Baltic For 17 (2): 268-279

4. BUSBY RJN, GRAYSON AJ 1981 Investment appraisal in forestry. Forestry Commission Booklet 47, London, UK, 90 p. URL: https://www.forestry.gov.uk/PDF/FCBK047. pdf/\$FILE/FCBK047.pdf

5. KEČA LJ, KEČA N, PANTIĆ D 2012 Net Present Value and Internal Rate of Return as indicators for assessment of cost-efficiency of poplar plantations: a Serbian case study. Int For Rev 14 (2): 1-12. DOI: https://doi. org/10.1505/146554812800923345

6. KEČA L, KEČA N 2012 Commercial Profitability of Poplar Plantation with Reference to the Damages Caused by Fungi. South-east Eur for 3 (1): 23-31. DOI: https://doi. org/10.15177/seefor.12-03

7. KEČA LJ, KEČA N 2014 Investment Appraisal in poplar Plantations in Serbia and it's Relations with Sustainable Land Management. In: Zlatić M, Kostadinov S (eds) Challenges: Sustainable Land Management - Climate Change. Advances in Geoecology 43, Catena Verlag GMBH, pp 287-297

8. KEČA LJ, PAJIĆ S 2010 Financial Aspects of Restoration in Poplar Plantations with Technology of Full Ground and Soil Preparation. International Conference "Land Conservation"- LANDCON 0905, Tara Mountain, Serbia, 2630 May 2009. In: Zlatić M (ed) Global Change Challenges for Soil Management. Advances in Geology 41, Catena Verlag GmbH, pp 321-334

9. KEČA LJ, PAJIĆ S 2015 Costs and revenues in poplar plantations established using full ground and soil preparation in Serbia. In: Ivetić V, Stanković D (eds) Proceedings: International conference Reforestation Challenges. 03-06 June 2015, Belgrade, Serbia. Reforesta, pp 234-241

10. PRICE C 1993 Time, Discounting and Value. Blackwell, Oxford, UK

11. THOMPSON W A, VAN KOOTEN G C, VERTINSKY I 1997 Assessing timber and non-timber values in forestry using a general equilibrium framework. Critical reviews in environmental science and technology 27 (S1): 351-364

12. GILLIS A M 1990 The new forestry. BioScience 40 (8): 558562

13. SNOWDON P, HAROU P 2014 Guide to Economic Appraisal of Forestry Investments and Programmes in Europe. EFI Technical Report 94, European Forest Institute, 31 p. URL: https://www.efi.int/sites/default/files/files/publicationbank/2018/tr 94.pdf
14. DAYANANDA D, HARRISON S, IRONS R, HERBOHN J, ROWLAND P 2002 Capital budgeting: financial appraisal of investment projects. Cambridge University Press, $344 \mathrm{p}$

15. GREGERSEN HM, CONTRERAS AH 1979 Economic analysis of forestry projects. FAO Forestry Paper 17, Rome, Italy, $193 p$

16. SHARPE WF 2011 Investors and markets: portfolio choices, asset prices, and investment advice. Princeton University Press, Princeton, New Jersey, USA

17. LUMBY S 1988 Investment Appraisal and Financing Decisions. Third Ed. Van Nostrand Reinhold Co. Ltd, England

18. BRUEGGEMAN WB, FISHER JD 2011 Real estate finance and investments. McGraw-Hill Irwin (5-6), New York, NY, USA

19. ALIG RJ, ADAMS DM, MCCARL BA 1998 Impacts of incorporating land exchanges between forestry and agriculture in sector models. Journal of Agricultural and Applied Economics 30 (2): 389-401. DOI: https://doi. org/10.1017/S1074070800008373

20. PIKE RH, WOLFE MB 1988 Capital budgeting for the 1990's: a review of capital investment trends in larger companies. Chartered Institute of Management Accountants

21. ROW C, KAISER HF, SESSIONS J 1981 Discount rate for longterm Forest Service investments. J Forest 79 (6): 367-376. DOI: https://doi.org/10.1093/iof/79.6.367

22. BRUKAS V, THORSEN B J, HELLES F, TARP P 2001 Discount rate and harvest policy: implications for Baltic forestry. Forest Policy Econ 2 (2): 143-156. DOI: https://doi.org/10.1016/ S1389-9341(01)00050-8

23. GITTINGER P 1972 Economic Analysis of Agricultural Projects. The Economic Institute, International Bank for Reconstruction of Development, The John Hopkins University Press, Baltimore-London

24. 2005. Serbia and Montenegro: Selected Issues and Statistical Appendix. IMF, Country Report No. 05/232, Washington D.C., USA, $127 \mathrm{p}$

25. KLEMPERER WD, CATHCART JF, HÄRING T, ALIG RJ 1994 Risk and the discount rate in forestry. Can J Forest Res 24 (2): 390-397. DOI: https://doi.org/10.1139/x94-052

26. HAROU PA 1985 On a social discount rate for forestry. Can J Forest Res 15 (5): 927-934. DOI: https://doi.org/10.1139/ x85-149

27. JOVANOVIĆ P 1999 Application of sensitivity analysis in investment project evaluation under uncertainty and risk. Int J Project Man 17 (4): 217-222. DOI: https://doi. org/10.1016/S0263-7863(98)00035-0

28. SQUIRE L, TAK HG 1979 Economic Analysis of Project. J. Hopkins, Baltimore, USA

29. CUBBAGE F, MAC DONAGH P, SAWINSKI J JR., RUBILAR R, DONOSO P, FERREIRA A, HOEFLICH, V, MORALES OLMOS V, FERREIRA G, BALMELLI G, SIRY J, NOEMI BAEZ M, ALVAREZ J 2007 Timber investment returns for selected plantations and native forests in South America and the Southern United States. New Forests 33 (3): 237-255. DOI: https:// doi.org/10.1007/s11056-006-9025-4 
30. HARDESTY SD, LEFF P 2010 Determining marketing costs and returns in alternative marketing channels. Renew Agr Food Syst 25 (1): 24-34. DOI: https://doi.org/10.1017/ S1742170509990196

31. KEČA LJ 2010 Estimation of cost-effectiveness of poplar wood production in Ravni Srem by applying the net present value method. Bulletin of the Faculty of Forestry University of Belgrade 101: 81-100

32. KEČA LJ 2010 Assessment of cost-efficiency for wood production in poplar plantations in Ravan Srem, based on internal rate of return. Bulletin of the Faculty of Forestry University of Belgrade 102: 25-40

33. KEČA LJ 2011 Estimation of cost-effectiveness of poplar wood production in poplar plantations in ravni srem based on the method of pay back period. Bulletin of the Faculty of Forestry University of Belgrade 103: 41-56
34. KEČA LJ 2011 Estimation of cost-effectiveness of poplar wood production in poplar plantations in Ravni Srem based on the cost-benefit method. Bulletin of the Faculty of Forestry University of Belgrade 104: 81-96.

35. LAMBERT DM, COOPER MC, PAGH JD 1998 Supply chain management: implementation issues and research opportunities. Int J Log Manag 9 (2): 1-20. DOI: https://doi. org/10.1108/09574099810805807

36. KEČA LJ, KEČA N 2015 Market potential dynamics for plantation-grown poplar forest products in Serbia. In: Ivetic V, Stankovic D (eds) Proceedings of the International Conference Reforestation Challenges, Belgrade, Serbia. 3-6 June 2015,

37. KEČA LJ, KEČA N, AVDIBEGOVIĆ M 2014 Development of marketing activities in production of logs in Serbia. In: Parrotta JA, Moser CF, Scherzer AJ, Koerth NE, Lederle DR (eds) Proceedings of XXIV IUFRO World Congress "Sustaining Forests, Sustaining People: The Role of Research", Salt Lake City, Utah, USA 5-11 October 2014 